\title{
MEMÓRIAS DE TRABALHO NAS PAISAGENS MISSIONEIRAS DO "ANIES-IEMPO"
}

\author{
Flávio Leonel Abreu da Silveira \\ Universidade Federal do Pará - Brasil
}

Resumo: $O$ artigo em questão estabelece reflexões em torno do tema do trabalho na região missioneira gaúcha, tomando como referência o legado das missões jesuítico-guaranis e seus desdobramentos no contemporâneo, a partir das memórias das pessoas que vivem naquela porção do Estado. Para tanto, o artigo se baseia numa pesquisa de campo de cerca de um ano, que teve como um dos interesses etnográficos a tentativa de compreender os processos de transformação das paisagens na região através das ações técnico-culturais relacionadas ao universo do trabalho.

Palavras-chave: memória, paisagens, sociabilidade, trabalho.

Abstract: The present article raises reflections on the thematic of work in the região missioneira gaúcha, a colonial missionary region in the extreme south of Brazil. The study uses as reference the legacy of the jesuitico-guaranis missions and their unfolding today, through the memories of the people who live in that portion of the Rio Grande do Sul State. For this, the article bases itself on field research conducted over approximately one year, which had as one of its ethnographic interests the attempt to understand the processes of landscape transformation in the region through technical-cultural actions related to the work universe

Keywords: landscapes, memory, sociability, work. 


\section{Introducão}

A partir da experiência etnográfica nas Missões gaúchas, ${ }^{1}$ o artigo em questão busca estabelecer uma reflexão em torno do tema do trabalho entre camponeses no noroeste do estado, de forma a refletir sobre os saberes e os fazeres relacionados a determinadas práticas de labuta que configuram um saber-viver por parte de seus habitantes junto às suas paisagens de pertença.

A experiência civilizacional das reduções jesuítico-guaranis de matriz hispânica engendrou o ethos do trabalho na região como um valor, exercendo a partir do processo da "conquista espiritual” uma série de ações técnico-culturais de manejo das paisagens sob influência de uma moral cristã associada à vassalagem dos súditos ameríndios a Castela na porção austral do Mundus Novus.

A experiência missioneira no século XXI é herdeira de práticas reducionais transformadas com o passar dos séculos na região, diante das vicissitudes e turbulências do tempo missioneiro, relacionada à ação humana de ocupar os espaços e de instaurar naquela zona de fronteira um processo civilizacional que possibilitou integrar a região ao processo colonialista português e, posteriormente, à moderna nação brasileira.

\section{A perspectiva da unicidade}

“A nossa mãe é a terra!... A terra, é bem certo, é nossa mãe legítima. Ela que nos dá a matéria!”, exclamou seu Antônio Furtado do alto de seus 83 anos de sabedoria, sentado em seu banquinho e com os pés descalços. Disse tais palavras para logo depois sorrir deixando à mostra a gengiva nua e rósea. O senhor vivia à época em São José, no interior de São Miguel das Missões, lugar do qual saiu poucas vezes. O seu apego ao lugar remete à ligação com o corpo-mãe da terra. Mas o "sacrifício”, o esforço de lidar com a matéria terrestre advém do pecado e da expulsão do Paraíso, pois de acordo com as suas palavras “o próprio hôme que desmontô o mundo, faz passá trabaio!”

\footnotetext{
Realizei pesquisa etnográfica na região noroeste do Rio Grande do Sul entre os anos de 2001 e 2002, que resultou em minha tese de doutorado Silveira (2004). Aqui faço uma observação necessária: mantenho a linguagem vernácula dos interlocutores da pesquisa a fim de conservar a fala corrente das pessoas, conforme a transcrição das entrevistas.
} 
Com essa frase seu Antonio lembra que as imagens bíblicas são recorrentes no mundo missioneiro, evocadas pelo "homem da tradição" (Durand, 1979) como referência à imagem poderosa da queda do Paraíso, porque introduz o ser humano no mundo do trabalho e ao sofrimento decorrente do esforço físico pela sobrevivência mediante o domínio da matéria terrestre. Nessa cosmovisão, o dilema vivido pelo humano é inerente à mitologia judaico-cristã. Seu Emílio, por sua vez, compartilha a visão bíblica com o tio: "O primeiro hôme teve que trabaiá, tirá o pão do suor de seu rosto!”, indicando que a imagem do "suor" escorrendo na face evoca a simbólica da labuta como destino e dilema humano no mundo.

Antes de adentrar na discussão relativa ao trabalho realizado sobre o corpo terrestre missioneiro, é preciso deixar claro que a visão de alguns de meus interlocutores aponta para o fato de que os processos ecossistêmicos e os cosmológicos são inseparáveis, quando as imagens convergentes de terra-mãe e da terra-organismo conformam uma unicidade, uma manifestação para além da dinâmica biofísica porque sensível e mental.

Pensando com Gregory Bateson (1986, 1990), sigo seus trilhos quando se trata de considerar a separação entre mente e matéria como algo que não é mais válido, daí a importância de encontrar “os padrões que unem” ambas. Para o autor, a natureza procede mediante processos mentais, fazendo as suas escolhas. A complexidade da matéria, nesse caso, é oriunda da realização de processos mentais ecossistêmicos nos quais a mente humana é uma de suas manifestações mais acabadas. O universo simbólico surge como um poderoso meio de onde aflora um mundo imaginal singular, proliferando metáforas. Estamos, portanto, na esfera de uma "ecologia mental” ou das ideias.

É nesse contexto que a terra é uma paisagem onde o homem se percebe como agente. A sua riqueza enquanto imagem geradora de sentidos é imensa. Expressão metafórica de tudo o que significa apego ao lugar e força cósmica que une o humano ao meio. Paisagens: a terra é dádiva e pertença, imagem de tudo o que é humano em sua aventura pelo mundo. A sua poética é a própria manifestação do ser. As paisagens falam do humano como seu Emílio parece sugerir: “Tá vendo aquela árvore ali! É que nem o hôme: nasce, cresce, morre pra dá lugar pras outras!” Afirmou isso, apontando para um capão de mato quando passávamos de carro, enquanto refletíamos sobre a questão da morte.

É por isso que a reflexão acerca das práticas de trabalho no espaço missioneiro remete a uma tentativa de compreensão da dinâmica do espaço-tempo 
vividos na relação sensível e proxêmica entre sujeitos e ambientes. ${ }^{2}$ Todavia implica em considerar a lógica contraditorial que emerge das pulsões humanas que oscilam entre construção e destruição, perdurância e ruptura, localismo e diáspora na conformação de paisagens sobre as quais a memória dos sujeitos deita suas franjas. A movência e a elasticidade da memória trazem à tona imagens do que, no universo missioneiro, representaria o "tempo das antiguidade”, ou ainda, aquele que denominam de "antes-tempo".

\section{A domesticação das paisagens: o "antes-tempo" e a pregnância da memória coletiva}

Havia um tempo outro. Uma época em que, tudo indica, o ritmo do mundo missioneiro vibrava de maneira diferente. Não havia máquinas agrícolas e ainda existiam matas em abundância. Reinava o "clima florestal subtropical" (Rambo, 1994, p. 409). O veado branco pastava junto ao gado nos campos e ocorriam animais na região dos quais já não se sabe o paradeiro. O trabalho era duro e os "rigores” da labuta - como vários idosos argumentaram - não impediam que as pessoas se visitassem com frequência. Num trecho do diálogo travado entre dona Cica e dona Geci isso parece ficar claro: "Era sacrificado!” (dona Geci); “Era dura a vida!” (dona Cica); "Era divertido, a gente tinha tempo de passeá!” (dona Geci), pois o tempo dos afazeres não era ditado pelo relógio.

As construções barrocas do período jesuítico-guarani estavam entregues à sua sorte, seguindo ritmos nativos de interação com as paisagens de ruínas do período jesuítico-guarani. É a esse tempo datado, por vezes, mas na maioria dos casos impreciso porque borrado pelo esquecimento e repleto de imagens dispersas - e interpretações diferentes - na memória coletiva dos moradores do lugar que se refere o "antes-tempo".

2 Os efeitos do modelamento de uma paisagem pelo grupo social implicam a manifestação de um onirismo, ou ainda, daquelas "forças oníricas que se extravasam sem cessar na vida consciente", oriundas do devaneio do repouso (e que se ligam aos devaneios da vontade), revelando o vínculo entre imagem e arquétipo, bem como a anterioridade da primeira em relação à percepção; além disso, a imagem abarca um caráter prospectivo que faz com que o homem que trabalha a matéria deva sonhá-la anteriormente: ele sonha as "imagens materiais" para que "a mão que trabalha" ponha "o objeto numa ordem nova, na emergência de sua existência dinamizada" (Bachelard, 1991, p. 3, 21, grifo do autor). Para Leroi-Ghouran (2002), imagem e gesto são inseparáveis na intenção inteligente de agir sobre a matéria e transformá-la.

Horizontes Antropológicos, Porto Alegre, ano 19, n. 39, p. 293-318, jan./jun. 2013 
Trata-se de um tempo de labuta e, dessa forma, de ação modeladora do meio biofísico que é possível acessar apenas através do "trabalho da memória” (Bosi, 1994) dos sujeitos que rememoram. Esse tempo deriva da experiência jesuítico-guarani, quando as paisagens passaram a ser domesticadas naquela região como uma das expressões do colonialismo hispânico na porção austral americana.

Naquele tempo as casas eram diferentes. Os latifúndios, herança da tomada de posse portuguesa ${ }^{3}$ via distribuição de sesmarias, ${ }^{4}$ com os seus enormes sobrados reinavam nas fazendas missioneiras. Gilberto Freyre (1973, p. 84-85) analisou a presença do sobrado no Rio Grande do Sul enquanto um dos "elementos da paisagem cultural brasileira". Longe da "aparência de uniformidade absoluta”, tais construções revelariam nas paisagens subtropicais uma "variação regional nos tipos de sobrados de origem portuguesa das várias regiões brasileiras”. Na verdade, era o complexo sobrado-senzala que compunha a "geografia do poder" nas terras missioneiras.

O cotidiano de trabalho dos escravos poderia ser controlado sem maior esforço pelo senhor a partir da janela de sua casa, de onde lançava seu olhar "superior" para a senzala, tamanha era a proximidade entre as duas esferas do vivido, os dois mundos que compunham o universo social da fazenda/estância, como foi possível observar na antiga Fazenda do Sobrado, localizada no município de Bossoroca. Portanto, dada a proximidade-distância tão tênue entre ambos os domínios é possível compreender o processo de miscigenação que ocorreu na região.

No "antes-tempo" não havia cercas. "No tempo do campo aberto tudo criava junto”, referindo-se aos animais, ponderou seu Pedro Tufão. O máximo

\footnotetext{
3 O açoriano a partir do "hábito da lavoura", como elucida Sérgio Buarque de Holanda (1978, p. 89), "tendia a formar no extremo sul uma casta de gente estável e sedentária".

4 As sesmarias aparecem como uma das formas de ocupação lusa do espaço missioneiro, ou seja, de "fracionamento do território", pois "é justamente nessa área missioneira que vai surgir a estância como centro de atividade econômica da pecuária. Constitui a estância a unidade social da organização regional; do ponto de vista econômico é um latifúndio, pela extensão que abarca, pelo tipo de atividade que desenvolve; nela assenta, por outro lado, a formação social, como célula de onde atuam os chefes e os líderes.” (Diegues Jr., 1960, p. 313). “A formação social do povo do Rio Grande do Sul assenta-se sobre o primitivo núcleo de produção rural a que se chamou ESTÂNCIA. Trata-se de um complexo familiar e comunal aplicado à criação, que se constituiu em linha mestra do desenvolvimento econômico desta região; uma sucessão de nexos ecológicos que criou um tipo de vida, característico linguajar e um sem-número de hábitos e atitudes.” (Xavier, 1969, p. 75).
}

Horizontes Antropológicos, Porto Alegre, ano 19, n. 39, p. 293-318, jan./jun. 2013 
que poderia existir eram valas separando as propriedades. Também existiam taipas - enormes muros que cortam os campos - com seu intrincado corpo longilíneo de pedras encaixadas umas às outras, recortando as paisagens missioneiras. Memória petrificada e engendrada pelo trabalho humano; em alguns casos, pela mão guarani, noutras, pela negra.

Técnica herdada que os missioneiros souberam aproveitar para delimitar as suas propriedades, bem como para facilitar o manejo do gado. A "cerca de pedra” ou taipa que existe na propriedade de seu Neto, morador do Campestre "tem uns quantos dias! Meu bisavô construiu naquele tempo que não tinha arame!... Depois apareceu os primeiro arame pra fazê cerca.” Ao tocar no assunto, levantou e seguiu em busca de um pedaço de arame liso e bastante velho, para mostrar-me como eram os primeiros tipos que surgiram na região, antes da figura ofensiva do arame farpado assumir o seu lugar na fragmentação do espaço agropecuário regional.

"Não tinha cerca. Cerca que eu conheci era a taipa de pedra dos Morais [na propriedade de seu Neto] e o valo!”, colocou seu Antônio Furtado. Nesse tempo, "o arame não existia" como algo que recortava a paisagem, por isso, para seu Dorcino "não é como dantes que podia cruzá [atravessar] por campo alheio... não tinha cerca!"

Lourenço Prunes (1969) ao falar da "humanização das paisagens" gaúchas aponta para o processo de modelamento técnico-cultural dos ambientes, demonstrando a experiência ecoantropológica que foi a estância. Ela surge enquanto atividade econômica ligada à pecuária - mas também é preciso considerar a presença do "estancieiro-agricultor" - nas paisagens rio-grandenses.

Paulo Xavier (1969), por sua vez, elucida aspectos da transformação da estância em fazenda, com as consequentes mudanças nas relações de trabalho no campo (e de compadrio, envolvendo a família patriarcal, os peões e os agregados) movidas pelo deslocamento paulatino da família patriarcal em direção aos centros urbanos. Assim, a estância torna-se "uma colmeia de trabalho voltada a economia mercantil” (Xavier, 1969, p. 83). Os dois autores fazem referência ao aramado, mas é Prunes (1969) quem descreve a "lenta estilização" definidora das mudanças na "paisagem sentimental” que era a estância. Segundo o autor,

muito mais tarde surgiram os aramados; a terra cinturou-se toda de arames sustentados em postes e tramas, e subdividiu-se em invernadas, potreiros e piquetes, enquanto que os limites dominais e as carreteiras também são balizados 
pelos moirões que seguram os tapumes de fios lisos e farpados. Com o carrapato apareceram os banheiros para os vacuns e novas configurações nas mangueiras, com a sarna multiplicaria os destinados a lavar as ovelhas e geraria bretes para melhor tratá-las. Plantaram-se tufos de árvores, quebrando a monotonia da paisagem, os quais tanto servem para abrigar os animais, quanto fornecem frutos. Mas essas estilizações apenas tocam a superfície do ambiente rústico... A disseminação da gente e o seu gênero de vida, o seu comportamento familiar, social e político, harmonizam-se com o ambiente e têm fundas marcas telúricas. (Prunes, 1969, p. 21-22).

Apesar da assimetria social inerente à relação entre sobrado e senzala, nos campos recheados de capões nativos da região missioneira, eram as taperas [pequenas casas ou ranchos de moradia] que reinavam. Singelas, manifestavam o caráter telúrico do "homem da tradição". Eram elementos inseridos nas paisagens evidenciando o bucolismo das formas de vida campeira diante do trabalho cotidiano.

Robert Avé-Lallemant (1980, p. 302) ao descrever a morada do naturalista francês Aimé Bonpland oferece uma imagem da casa na região platina:

Avistamos, afinal, diante de um vergel, uma pequena granja. "Ali mora Dom Amado" - disse meu peão - e poucos minutos depois parávamos diante da casa. Todavia a palavra casa deve ser tomada em sentido eufemístico. A morada do velho Aimé Bonpland perto de Restauración, em Corrientes, consistia em duas grandes cabanas que se encontram em ângulo reto do lado da entrada, cujas paredes de barro são sustentadas por varas de bambu e algumas traves. O teto de palha repousava sobre bambus. Ao lado dessas duas grandes cabanas, uma espécie de choça, tendo no chão pedras reunidas: cozinha e fogão de célebre homem. Ao lado do conjunto, uma carreta velha e algumas estacas para secar a carne e amarrar os cavalos.

Nas casas modestas do gaúcho missioneiro existe desde longa data um despojamento que engendrou raízes, permanecendo até os dias de hoje como uma manifestação estética marcada pelo desapego. Mais do que pobreza relativa, parece ser signo da valorização de questões diversas ao mero acúmulo de bens. É por isso que no meu ponto de vista algumas casas recentemente construídas na paisagem urbana miguelina ${ }^{5}$ destoam do conjunto singelo

5 Referência à “terra miguelina”, como dizem os moradores de São Miguel das Missões.

Horizontes Antropológicos, Porto Alegre, ano 19, n. 39, p. 293-318, jan./jun. 2013 
das moradias dos habitantes locais, mesmo daquelas das sedes das fazendas no interior do município, tomando os fazendeiros como aquele estrato social considerado como "apoderado"6 pelos moradores locais. A casa cumpre o papel de ninho (Bachelard, 1988), representando a "morada”, e não há interesse nas aparências como signo ostentatório de riqueza mesmo entre alguns fazendeiros.

Seu Dorcino, numa das tantas visitas que fiz à sua casa, falou sobre como "os antigo" construíam as suas moradias. Para edificá-las, contou, utilizavam ripas envoltas por barro, usando capim santa-fé para cobri-las, mas depois passaram a fazer o telhado com ripas de guajuvira e guabiroba. Eram de chão batido. Tais casas foram comuns até cerca de 60 anos atrás, segundo o idoso. A arquitetura rústica dessas moradias das comunidades caboclas era uma derivação das técnicas de habitação herdadas dos indígenas que, com o passar do tempo, foi alterando-se em função da incorporação de novas tecnologias no trabalho de construção.

Dona Cica afirmou que elas eram construídas de "taquara bem juntinha e rebocavam com barro". Esclareceu que para a construção do piso "juntava barro com esterco de gado". Além disso, "as casas não eram com telhado assim; os bem pobrezinhos, era coberta de capim!” Dona Narcisa, por sua vez, mencionou o fato de as casas terem as suas telhas "com tabuinha", quando não, "de macega".

Seu Emílio - que morou numa casa desse tipo com dona Cleni, sua esposa - comentou que o ripado das paredes era rebocado utilizando-se na tarefa uma massa de "barro e esterco de vaca". Segundo ele, "fazia uma grade e atava com cipó", e concluiu que "no inverno é bem quente e no verão era frio". Engenhoso, sentenciou: "quase ninguém sabe fazê, eu sei fazê!"

A proximidade com "as criação" [gado bovino; equino; ovino; suíno; galináceos] é um aspecto interessante da forma de viver do "homem missioneiro" (Freyre, 1973), em que a presença constante dos animais no entorno ou, por vezes, no interior das moradias é algo corriqueiro - especialmente galinhas; filhotes de ovelhas -, compondo as paisagens domésticas. Há uma convivência pacífica e fundamental entre elementos da paisagem na dinâmica

6 O mesmo que “empoderado”; rico. 
ecoantropológica que constitui a variedade de sistemas complexos do tipo moradia-pátio-roça na zona rural.

A casa missioneira (e seu entorno) está integrada às paisagens nativas, consorciada com espécies animais e vegetais exóticos. Ela liga-se ao eixo mangueira-potreiro quando aparecem (o que é frequente), gerando mosaicos de ambiências que definem desenhos singulares nos espaços e marcas diversas nos lugares de convívio e trabalho. Uma propriedade é um universo de possibilidades engendradas pela ação transformadora, delineando formas distintas pela ação modeladora do gesto humano através da labuta.

A roça ${ }^{7}$ é um lugar de trabalho que representa o espaço humanizado, cujo manejo incorre no domínio de certas técnicas reveladoras da ação transformadora do homem sobre o meio, imprimindo sua vontade em rearranjá-lo de acordo com determinadas necessidades e ordens simbólicas de interação com o cosmos, dentro de uma lógica de produção voltada para a subsistência familiar. Nesse sentido, o método tradicional denominado de coivara ${ }^{8}$ apresenta-se como uma prática técnico-cultural importante no contexto missioneiro.

Por certo, nessa forma de manejo dos ambientes os lugares intrincados da arquitetura botânica são reordenados, os espaços ampliados a partir de uma intervenção técnica de “descoivará”, bem como na "limpeza do mato” para o cultivo das roças, sugerindo cosmologias agrárias: ao derrubar o capão funda-se um mundo, uma nova ordem cósmica em que o trabalho na roça domestica o caótico polimorfismo do mato. A transformação diz respeito às imagens e às categorias de pensamento ligadas ao trabalho e ao cultivo de vegetais, colocando uma nova ordem de organização no espaço praticado (Certeau, 1994) e, em última instância, referindo-se ao mundo da casa enquanto outro centro sagrado.

A coivara é um sistema de cultivo guarani que foi assimilado pelas comunidades rurais e mestiças, assim como pelos "de origem" (ítalo e teuto-brasileiros, principalmente). Trata-se de uma atividade na qual as pessoas realizam o sistema de "derrubadas” - “atorá madera”, segundo seu Dorcino -, onde uma porção da mata é colocada abaixo, servindo, inicialmente como

\footnotetext{
Sobre a questão da importância da roça nos modos de vida caipira, por exemplo, ver o trabalho clássico de Antonio Candido (1964).

8 Sobre o sistema de coivara entre os Guarani, ver Brochado (1975), Inácio Schmitz (1979), Haubert (1998) e Kern (1982, 1985, 1998). Entre os Caiapó, ver Anderson e Posey (1987); no que tange às comunidades caiçaras do litoral paulista, ver o trabalho de Oliveira et al. (1994).
} 
uma espécie de cerca, pois ao mesmo tempo em que paulatinamente se decompõe permite que a mata rebrote, impedindo, assim, que o gado saia da propriedade. Seu Emílio comentou sobre o caso do feijão preto que não suporta o vento sul, portanto tal técnica beneficia o seu cultivo, pois o mato serve como proteção devido ao fato de que "o tempo varia muito". Essa técnica, por vezes, poderia estar associada ao sistema de valas como forma de impedir a dispersão do gado pelo local.

O médico alemão Robert Avé-Lallemant (1980, p. 217-218) descreve uma paisagem de coivara em 1858, surpreso pelo aspecto de ruína que presencia:

Em toda a parte encontramos culturas iniciadas e o começo de uma bem feita estrada carroçável que daqui, de regiões solitárias, das antigas Missões, vai até ao Uruguai. Decerto passa ela, a princípio, através de um terrível campo de batalha! Aqui a floresta sofreu desesperadamente do ferro e do fogo. De pé ou caídos se vêem, à esquerda e à direita, troncos carbonizados, horrível quadro da feroz destruição com que, quase em toda parte, começa a agricultura no Brasil. Consola ver, imediatamente ao lado, o verde jovem que, como bem cuidadas plantas de cultura, brota entre os montes de cinza e montanhas de carvão.

Nem sempre a madeira era aproveitada para o consumo, podendo ser assimilada pelo sistema de reciclagem inerente ao ecossistema manejado. O ato de descoivarar, ou seja, de derrubar a mata ateando fogo para após destocar a área era uma prática comum dentro de um sistema brando de produção agrícola. A derrubada e a consequente queima do seu produto eram realizadas dentro de um sistema de "pousio". Após os sucessivos cultivos a terra era abandonada à sua sorte para que a mata fosse reconstituída. Em relação ao cultivo do "fumo de folha pra fazê rolo" - no sistema tradicional do cultivo da espécie -, seu Emílio ensina que "planta direto depois da queima”, ou seja, faz-se a queima no meio do mato, pois o seu cultivo ocorre junto às cinzas.

As comunidades missioneiras faziam rodízios de culturas. ${ }^{9}$ Da mesma forma que os grupos indígenas abandonavam as roças ao seu destino,

9 A “existência de todo grupo social pressupõe a obtenção de um equilíbrio relativo entre as suas necessidades e os recursos do meio físico, requerendo, da parte do grupo, soluções mais ou menos adequadas e completas, das quais depende a eficácia e a própria natureza daquele equilíbrio. As soluções, por sua vez, dependem da quantidade e qualidade nas necessidades a serem satisfeitas.” (Candido, 1964, p. 9).

Horizontes Antropológicos, Porto Alegre, ano 19, n. 39, p. 293-318, jan./jun. 2013 
permitindo que ocorresse um processo de sucessão ecológica na qual as espécies nativas recolonizavam a área em repouso, ou seja, as plantas cresciam "guaxas" ("que nasce por conta") reconstituindo a vida do solo e permitindo que sua biodiversidade edáfica se recuperasse associada à diversidade vegetal que nele aflorava, de maneira a possibilitar o retorno dos bichos ao mato.

As falas dos interlocutores deixaram claro que até a segunda metade do século XX, as comunidades missioneiras cultivavam as roças mediante a prática da coivara, pois plantavam em terras de matas aproveitando a riqueza mineral oriunda das cinzas para ativar a produção agrícola, que nos primeiros anos de cultivo era significativa. José Herter recorda que cultivavam em "terra nova, terra de mato” em Caibaté, ou ainda, conforme seu Emílio, "antes do trator o pessoal plantava em terra de mato, não de campo!”

Em São Miguel, de acordo com as rememorações de seu Emílio, havia "fartura”, pois plantavam inúmeros vegetais: "feijão preto, lentilha, milho, rama [de mandioca], cana-de-açúcar, batata-doce, arroz, amendoim... e não tinha o que não criasse, as criação, tudo o que era quinta... bastante erval”. Logo, antes do advento da mecanização intensiva, as pessoas trabalhavam nas roças familiares a partir da derrubada e da queima da vegetação florestal. Dona Cleni, certa vez, contou que quando veio morar na cidade com sua família, sentia vergonha em comprar alimentos no supermercado, pois outrora produziam tudo o que necessitavam para a alimentação.

A coivara não representava a destruição dos ecossistemas nativos, pelo contrário, o manejo realizado pelas comunidades missioneiras introduzia uma dinâmica transformadora das paisagens, modelando-as e não aniquilando seus componentes. Tal ação modificadora, mediante a abertura de clareiras no mato, fazia com que as espécies nativas ocupassem nichos ecológicos diversos, dispersando sementes, havendo troca genética e convivência de espécies num espaço novo.

A partir do momento que essas áreas eram recolonizadas espontaneamente pela floresta, davam origem a formações vegetais novas. Além disso, tudo indica que as comunidades missioneiras realizavam formas nativas de melhoramentos genéticos das espécies vegetais autóctones, como o milho, a batata e a mandioca, por exemplo. "Era fartura. Dava pra escolhê! O pessoal era menos e ninguém tinha destruído com as mata ainda”, afirmou seu Emílio, relembrando a sua infância e adolescência. 
Havia, portanto, a produção de espaços humanizados - as roças - que consorciavam as espécies nativas com as exóticas, de forma branda e não aniquiladora da biodiversidade local. As pessoas estavam inseridas de maneira outra à bioetnodiversidade (Rocha, 2000) regional, mediante dispositivos culturais junto ao meio que acionavam dinâmicas de interações ecoantropológicas, onde a cultura e a natureza não conheciam a cisão dada pela intervenção das práticas técnico-culturais duras nas paisagens através da mecanização. Os impactos sobre as paisagens eram de outra ordem, assim como suas consequências sociais.

No entanto, com o processo de introdução do sistema capitalista de produção no meio rural missioneiro, com maior intensidade a partir da segunda metade do século XX, essa prática tornou-se danosa pela falta de critérios na sua execução ante a demanda de lavouras extensivas e o crescimento das agriculturas mecanizadas, nas quais reina a pobreza vegetal da monocultura. A associação, num primeiro momento, com instrumentos como a serra, introduzida pelos “de origem”, segundo ouvi de algumas pessoas, parece ter iniciado um processo de devastação que culminou com a entrada de trator de esteira como elemento arrasador de extensas áreas florestadas da região noroeste do estado gaúcho.

Certo dia quando retornava da casa de seu Dorcino na Vila da Alegria, encontrei seu Juca Tigre que vinha em direção à sua morada. Resolvi acompanhá-lo até a sua casa. No caminho contou-me que cultivava uma roça - numa área de 20 x 50 m - na horta comunitária, área cedida a ele pela prefeitura municipal por tempo indeterminado, a qual viria conhecer posteriormente, e onde trabalham diversas pessoas da comunidade que, como ele, necessitam de terrenos para seus cultivos. Seu Juca, naqueles dias de intenso calor e pouquíssimas chuvas, habituou-se a trabalhar na roça das seis às nove horas da manhã, como forma de evitar os rigores do sol.

O idoso contou que planta milho, rama [mandioca], mogango, abóbora, feijão graúdo e arroz. Comentou que trouxe sementes de mogango de Porto Alegre para cultivar na área. Queixa-se de jovens ladrões que roubam o fruto de seu trabalho. Logo depois, quando conversávamos na varanda de sua moradia, seu Juca Tigre falou animadamente sobre os progressos de sua roça, mas reclamou novamente da "ladroage" realizada pela "rafoage" que vive na vila. Por vezes, quando falava, tinha a impressão de que a qualquer momento 
perderia a sua dentadura, pois me pareceu meio solta, sendo visível a falta de um dente. Dias depois diria que estava indo a Porto Alegre visitar sua filha e "pra arrumá a chapa que tá floxa!” No entanto, seguia viagem preocupado com os possíveis furtos sobre o seu trabalho.

"A pranta toda vida eu gostei... eu gosto de prantá, toda a vida eu gostei!”, refletiu quando conversava comigo sobre a sua roça. Mas sentenciou: “Na lavora o pobre não tem mais chance de ganhá!”, pois é necessário trabalhar muito para ganhar pouco.

Nota-se que o trabalho na roça representa a luta incessante das pessoas contra e a favor da matéria, porque a ambivalência está em negá-la a fim de aderir à sua modelagem, construindo ambientes nos quais as imagens idealizadas florescem e os sentimentos se infiltram, adentrando a sua organização e engendrando formas por intermédio de uma construção humana. Edificar, domesticar, cultivar equivale a ações que consubstanciam formas plurais a partir do gênio humano. As paisagens missioneiras nativas são reflexos dessas pulsões primevas que dinamizam o espaço e perduram no tempo. ${ }^{10}$

O domínio de algumas técnicas e instrumentos desde longa data mostrou-se necessário para a produção alimentar, mediante os resultados dos cultivos nas roças, bem como do extrativismo realizado no mato, visando à subsistência dos grupos familiares. O uso do pilão, técnica guarani que "o gaúcho usava até pra socá charque, milho, arroz, tudo o que é semente”, explicou seu Emílio, aparecia como fundamental dentro do sistema de produção nativo. Dona Cica, ao recordar as suas atividades domésticas falou do tempo em que "socá canjica e arroz no pilão" era uma atividade que executava dentro da divisão do trabalho familiar.

A "era” consistia em um pano sobre o qual batiam o feijão, mas "só depois se usou o pano”, considerou seu Emílio. Ele recordou que "de primeiro, quando era gurizote" usava-se esterco batido, se tratando de "um quadro grande, 30x40 m”, no qual "se reunia a paia [palha] pra batê, debuiá: feijão,

\footnotetext{
10 A importância das reflexões de Marshal Sahlins (1990, p. 9) para o tema reside "na existência e na interação dual entre a ordem cultural enquanto constituída na sociedade e enquanto vivenciada pelas pessoas: a estrutura na convenção e na ação, enquanto virtualidade e enquanto realidade. Os homens em seus projetos práticos e em seus arranjos sociais, informados por significados de coisas e de pessoas, submetem as categorias culturais a riscos empíricos. Na medida em que o simbólico é, deste modo, pragmático, o sistema é, no tempo, a síntese da reprodução e da variação.”
} 
araruta, linhaça". Dona Cica mencionou o uso do "manguá", ${ }^{11}$ que é um instrumento agrícola utilizado sobre "a era de batê feijão”. A senhora também comentou que antes misturavam barro com esterco para bater a vagem em cima. Seu Neto, por sua vez, mencionou a "era” como um pano de algodão de bater feijão onde se batia com o manguá.

O gadanho é outro instrumento agrícola citado pelas pessoas, cuja lâmina apresenta cerca de $60 \mathrm{~cm}$ de comprimento por $10 \mathrm{~cm}$ de largura, apresentando um cabo longo. Seu uso estava associado ao corte de alfafa, por exemplo.

\section{As máquinas tradicionais e as formas de trabalho nas Missões}

Na região missioneira, no "antes-tempo", coexistiam pelos menos quatro tipos de "maquinários" nativos utilizados para a execução de diferentes trabalhos nas comunidades locais. O trabalho, nesse caso, correspondia à ação das tecnologias nativas adaptadas às formas de vida do "homem da tradição" e, portanto, inseridas nas paisagens manejadas pelas comunidades: o "manjolo" (monjolo), a atafona, o engenho de cana e o alambique de cachaça.

No interior de São Miguel das Missões existe uma região denominada de Manjolo - também ouvi referências ao Forno Velho -, pois existiria no local um "forno véio". Nessa região estariam presentes ainda as atafonas. Segundo seu Emílio o manjolo e a atafona "foram muito usados por aqui”. Seu Frutuoso afirmou que em Palmeira das Missões até bem pouco tempo atrás, em torno de 25 anos, os "manjolos" estavam em atividade.

O "manjolo" era uma estrutura movida pela força d'água que acionava um dispositivo que fazia cair uma madeira pesada sobre o milho, o arroz e a erva-mate, a fim de produzir farinha (e fazer canjica), descascar e socar tais produtos, oriundos do trabalho de cultivo nas roças e nos ervais. Tanto seu Emílio quanto seu João Mosquito fizeram referência a ele. Maximiliano Beschoren (1989, p. 26) descreveu o mesmo em 1874, durante as suas andanças pela região noroeste do estado:

Permanecemos dois dias na casa de João Castelhano. Apesar de estar há quatro anos no país, vi aqui, pela primeira vez, uma "Máquina" brasileira, que não se

11 Trata-se de um “equipamento usado na trilha (debulha) de grãos” (Silva, 2000, p. 56). 
encontra nas colônias alemãs: o monjolo. É um triturador que substitui o nosso moinho. A disposição interna e externa lembra uma rústica habitação. É constituído por uma alavanca. Numa extremidade, há um moedor pontudo, feito da mais resistente madeira. Na outra extremidade, mais larga, há uma escavação, uma espécie de gamela. Esta alavanca está colocada entre dois postes eretos, de tal modo que, a gamela quando está cheia, pela água represada, a extremidade afunda e o moedor se ergue. Quando a água escorre da gamela, o moedor cai de volta com toda a força sobre a selha de madeira. Este monjolo realmente não falta em nenhuma casa de família, nos distritos florestais. Serve para triturar o milho, fazer canjica e farinha. Para obter a farinha de milho, deve-se deixar o milho na água durante uns dias. Depois é batido no monjolo até se transformar em papa que, em pequenas porções, é colocada para secar numa frigideira bem quente, formando o beiju. Nos distritos da floresta materia, o monjolo é especialmente usado para bater e triturar a erva-mate.

A atafona, por sua vez, era um tipo de engenho utilizado para a produção de farinha de mandioca a partir da moagem da "rama” [mandioca]. O instrumento era movido por tração animal, da mesma forma que o engenho de cana-de-açúcar, cuja atividade produtiva estava associada ao alambique de cachaça. Vi um desses em ruínas na propriedade de seu Alfredo, que foi alambiqueiro por muito tempo no Rincão dos Ataídes, no interior de São Miguel. A sua família quando chegou ao Brasil substituiu a produção de bebidas fermentadas à base de beterraba, como estavam acostumados na Hungria, pela de cana-de-açúcar. Na propriedade de seu Maneco vi uma pequena roda-d’água desativada.

Numa conversa com seu Juca Tigre em sua casa, o senhor afirmou que "naquele tempo eu trabaiava no engenho, de gurizote... de doce, de cana, né!”. Contou que trabalhava muito a ponto de seus pés sangrarem. Em certos dias o sangue escorria pelos seus pés de tal maneira que "colava nos tamanco”. Por vezes, trabalhava embaixo de geada, comentou.

Esses engenhos agrícolas, heranças do sistema colonial, praticamente desapareceram das paisagens missioneiras. Em algumas localidades talvez seja possível encontrar algum deles ainda em funcionamento. Há uma retomada da produção de cachaça em alambiques na região, voltada para o consumo do "tradicional" pelo turismo. As máquinas nativas aparecem, na sua maior parte, enquanto resquícios dispersos pelas fazendas, ou em ruínas, sem a importância que detiveram no passado. 
O carijo era uma construção utilizada para a produção de erva-mate. Nele os feixes de erva-mate depositados sobre jiraus ${ }^{12}$ secavam pela ação do vapor que era conduzido até o local pelo barbaquá, constituindo-se, esse, numa parte do carijo na qual se fazia "uma barroca” [buraco] com uma "esteira de madeira”, ou ainda, "uma valeta no chão, uma cova lá na frente. Ali arrumava bem pra botá terra em cima da valeta que foi feita. Botava fogo na entrada da valeta e saía o vapor no carijo!”, ensinou seu Emílio.

Ele faria referência ao uso de certas espécies vegetais na queima da erva-mate para dar-lhe um sabor agradável. As três primeiras espécies citadas por Maximiliano Beschoren também são mencionadas por ele. Confirmaria, ainda, as considerações do viajante alemão no que se refere à perda da produção de erva-mate devido ao descuido com o manejo do fogo, durante a secagem dos feixes da planta, como aquele presenciara no século XIX.

Numa visita que realizei à casa de seu João Mosquito e dona Nena, perguntei ao senhor se ele lidara muito com carijo. A sua resposta foi um sonoro “bá!”. A partir desse momento, o tom de sua narrativa tem algo de evidente empolgação, ficando claro que a labuta no carijo desempenhou um papel importante em sua trajetória de vida, no que tange a um amplo conjunto de significados e sentimentos relacionados ao trabalho - mas, também, ao hábito de preparar a erva para tomar chimarrão - que subitamente emergem dos fluxos de sua memória.

Contou, ainda, que certo Vardo Castanha era dono de um erval na região. Segundo ele, tratava-se de um "erval de duas hectaria povoado de erva” no qual trabalhou durante certo tempo - "era um mês, dois, desgaiando erva” -, para logo após iniciar o processo de produção do mate. Seu João Mosquito referiu-se ao barbaquá como um "cano” que veicula o calor para secar a erva. De acordo com o idoso "entrava o calor ali e saia lá”, secando a erva. "Era tudo de tijolo”, esclareceu.

\section{Labuta e ludismo nas paisagens missioneiras}

Pelo que tudo indica é nesse contexto de produção agrícola e de manejo das paisagens missioneiras que o “puxirão” deve ter existido enquanto prática

12 “Estrado de madeira ou de varas onde são guardados os produtos de colheitas ou fenos.” (Silva, 2000, p. 51).

Horizontes Antropológicos, Porto Alegre, ano 19, n. 39, p. 293-318, jan./jun. 2013 
social, pelo menos até cerca de 20 ou 25 anos atrás na "terra miguelina". Tratava-se de uma atividade de trabalho coletivo dentro do caráter cíclico do calendário agrícola, representando uma forma de coesão social que reafirmava os laços de solidariedade entre os grupos, de maneira a fortalecer as práticas culturais ligadas à labuta e ao lúdico. Era, portanto, uma "ordem de significação” posta em prática na ação coletiva aderida a uma simbólica específica. "Se tivesse um serviço que visse que tu não ia terminá no tempo certo que tu percisasse, convidava a vizinhança: quem ganhava convite era difícil faiá uma pessoa", ${ }^{13}$ esclareceu seu Emílio.

Isso acontecia, em parte, porque "amontoava serviço”, tornando difícil para o "colonho" trabalhar na sua roça e gerir a espacialidade do lugar para a sua produção agrícola. Portanto, necessitava de auxílio do "próximo" para executar as tarefas que giravam em torno de "ará terra, capiná, prantá com saraquá”, especialmente "pra prantá o milho”.

O saraquá consistia numa madeira de cerca de dois metros de comprimento com a ponta afilada com a qual perfuravam o solo, para daí lançarem as sementes e cobri-las em seguida com a terra. Segundo seu Emílio, teria sido "o primeiro prantio que aconteceu!". No cultivo as pessoas traziam consigo, durante a semeadura, "uma sacola de pano com semente, cravava o saraquá, abria a terra e largava a semente a um passo de distância de cada cova”, isso equivalia a "um metro de distância de uma linha à outra", onde cultivavam especialmente o milho.

Esse instrumento agrícola tradicional foi substituído pela máquina de soco, por vezes denominada de saraquá. Na verdade, ela "veio fazê a veiz do saraquá”, explicou o senhor. A sua presença escasseou nas paisagens agrícolas missioneiras, mas ocasionalmente, ainda pode ser visto algum trabalhador utilizando-a no cultivo de sua roça. Observei algumas vezes pessoas trabalhando com este instrumento agrícola em São Miguel. As técnicas nativas de cultivo estavam inseridas no trabalho coletivo que era o puxirão.

\footnotetext{
13 Antonio Candido cita a fala de um caipira que menciona o "tempo de caridade", referindo-se ao mutirão. Antes, menciona, para o contexto paulista, a referência feita pelo viajante D’Alincourt (1818) do “muchiron”, assim como Ayrosa (1934) do “muchirão” que, segundo este último "não é propriamente um socorro, um ato de salvação ou movimento piedoso; é antes um gesto de amizade, um motivo para folgança, uma forma sedutora para executar rapidamente um trabalho agrícola” (Candido, 1964, p. 4849). Rosane Rubert (1999) menciona o “puxiron” como uma atividade de trabalho coletivo solidário para a região nordeste do Rio Grande do Sul.
}

Horizontes Antropológicos, Porto Alegre, ano 19, n. 39, p. 293-318, jan./jun. 2013 
É preciso deixar claro que o sistema de puxirão era circular, pois mal terminava um e "já saía convite pra outro". O puxirão "circulô muito aqui antes de vir esses maquinário”, recordou seu Emílio. Comentaria que "dispois do puxirão, à noite, saía um bailezinho... vortava com a família pra se diverti!”. Então: "Carneava porco, ovelha, as veiz vaca, galinha". "Isso era uma festa, pode dizê, uma festa!... Pra ti vê como o povo era unido!” Mencionou que "hoje em dia se chegasse a fazê isso aí, sabe o que ia acontecê?... Io chamá os otro de vagabundo... uma palavra que não era de dizê!”

Seu Pedro Tufão falou com nostalgia dos tempos em que se realizavam puxirões “pra quarqué serviço... tem amizade bastante. Tem puxirão pago!” Mas também menciona o "puxirão de carinho!” Ou seja, havia diferentes modalidades de puxirões dentro de uma comunidade.

Existiu também uma prática de trabalho denominada de "quarteada". “Tu sabe o que qué dizê?”, perguntou seu Emílio. “É troca de serviço... trabaia tantas hora pro otro, aí fica devendo, depois vem pagá!”, esclareceu. A quarteada, no entanto, é diferente do puxirão, mas não deixa de ser uma troca de prestações de serviços entre os moradores da zona rural missioneira. Os tropeiros, quando se revezavam nos cuidados com o gado, executavam a prática de "quarteá”, por exemplo.

Seu Dorcino mencionaria o "puxirão pra derrubá mato" como um exercício coletivo de manejo das florestas subtropicais pelas comunidades missioneiras. Já seu Pedro Cigano, frente às mudanças do espaço miguelino e às transformações das práticas sociais oriundas do processo de ocupação das áreas que compõem a zona urbana, bem como a redefinição de comportamentos em função do "progresso", ${ }^{14}$ diria que "lá onde tem o hospital eu carpi... Fiz um puxirão!... Nem se fala mais! ... Não tem no que fazê puxirão, ninguém planta mais!”

Numa tarde em que conversamos sentados na varanda acolhedora de sua morada, seu Juca Tigre mencionou o puxirão, quando "juntava vinte e poucos hôme, na enxada!”. Era “um ajutório!”. Mas “terminô, ninguém ajuda mais o

\footnotetext{
${ }^{14}$ Marshal Sahlins (1990, p. 174), discutindo acerca de sua “teoria da história”, afirma que a "relação entre estrutura e evento, que se inicia com a proposição de que a transformação de uma cultura também é um modo de sua reprodução". Mais adiante o autor coloca que "no mundo ou na ação - tecnicamente, em atos de referência - categorias culturais adquirem novos valores funcionais. Os significados culturais, sobrecarregados pelo mundo, são assim alterados. Segue-se então que, se as relações entre as categorias mudam, a estrutura é transformada.”
} 
otro", pois agora "o pessoal qué tirá um do outro... Agora ninguém mais se importa, ninguém mais dá mão pra ninguém!” O idoso refletiu acerca do tempo e as relações sociais imersas no seu fluir: "É o tempo que mudô, qué dizê, o tempo é o mesmo, mas o pessoal!"

No tempo em que ocorriam puxirões as pessoas iam de roça em roça auxiliando as demais. "Ia recorrendo", nas palavras de seu Juca. "Limpava um mundo de roça!” Demonstrou que foi solidário com as pessoas de sua comunidade: "Eu fui muito!” Confirmou que após o puxirão “as veiz tinha um baile”, porém, “não faiz mais”, “acabô tudo!”

Havia "brinquedo de faca” contou seu Juca, mas nunca episódios de violência. O comensalismo era parte importante do ritual: "Aquilo era leitão assado, rêis assada, galinha assada, peru assado.” O signo da fartura e a experiência da dádiva compartilhada periodicamente eram festejados através de um ludismo ritual, pois “de noite roncava um baita baile!” Mencionou uma determinada localidade como um lugar no qual "dançavo quase todo o final de semana".

Nesse tempo “era a coisa mais linda! Tudo se dava!” Os bailes que se seguiam atravessavam a noite. "Depois saía o sol, fechava a porta. Levantava o pó, não tinha soalho!”... “A coisa de primeiro era muito delicada, coisa de respeito!”, rememorou seu Pedro Tufão.

Mara Morais, proprietária de terras no Campestre e ex-moradora da Esquina Mosquier em Entre-Ijuís, comentaria que nessa última localidade, “faz bem pouco tempo”, ocorriam puxirões na propriedade em que morou, mais especificamente durante a colheita do trigo. Acredita que tais associações ainda ocorram em determinados locais da região missioneira.

Por mais que os fazendeiros tenham incorporado esta prática tradicional de trabalho coletivo em suas tarefas nas lavouras mecanizadas, o puxirão enquanto atividade social está relacionado ao “antes-tempo”, exatamente por estar ligado a um período no qual os implementos agrícolas mecanizados não faziam parte das paisagens missioneiras. Época em que as pessoas se solidarizavam umas às outras de forma intensa, ao mesmo tempo em que buscavam, a partir do estar-junto de caráter afetivo e ritual (Maffesoli, 1987), experimentar formas de sociabilidade ${ }^{15}$ em que a vivência lúdica era a culminância do dia de labuta.

15 Utilizo o conceito a partir de Georg Simmel (1983) como um tipo de sociação no qual as pessoas se entregam por livre e espontânea vontade. 
A “surpresa”"16 também poderia acompanhar o puxirão. Tratava-se de um tipo de sociabilidade que parecia misturar jocosidade com comunhão de abundâncias, na qual se compartilhavam riquezas num ritual lúdico, quando labuta e festividade se entrelaçavam, emergindo como expressão da vida missioneira.

$\mathrm{O}$ acontecimento inusitado tomava corpo quando um grupo de brincalhões chegava à casa de determinada pessoa em meio a grande algazarra, tocando gaitas e dando tiros para o alto. As pessoas chegavam "desnucando as galinhas” e jogando-as para os donos prepará-las. Carneavam porcos e dançavam. Era um rito sacrificial, uma festa dionisíaca marcada pelo querer estar-junto como potência de interação e compartilhamento de imagens e sentimentos ligados à fartura sazonal das colheitas, e à reprodução da vida numa referência ao mito do eterno retorno (Eliade, 1992).

"Tinha a tal de surpresa”, quando chegavam pessoas na propriedade, por vezes, uma "carreta cheinha de gente" e "acordava a tiro" o anfitrião, contou seu Juca Tigre. "Como usavo fazê baile; surpresa, antes-tempo!” Chegavam carneando porcos, mas também "abriam conta no comércio” no nome do anfitrião para que bancasse a festa.

A surpresa era aplicada em tempos de bonança. Portanto, no interior dos grupos existia uma observação recíproca dos ritmos produtivos dos seus integrantes a fim de planejarem as investidas nas propriedades alheias, dentro de um clima de diversão. Havia um plano no rodízio, uma intencionalidade em aplicar a surpresa ao outro. Por isso a existência de um clima de vingança - não rancorosa, mas de malandragem cabocla -, pois um "se vingava no otro" fazendo com que os sujeitos agissem por uma perspectiva semelhante à de seu Juca Tigre, ou seja, de que “o dia que eu botá uma surpresa em vocês eu levo tudo!”

Nas festas dançava-se o xote laranjeira, entre outras coreografias. Também poderiam bailar uma "vanera de dama", quando "elas é que tirava o par, os rapaiz... e a moça tinha que cantá um verso, e depois o rapaiz”. Nesse momento de sua narrativa seu Juca recitou um verso:

Se eu errá contra a razão

Muito tenho que senti

Tanto bem que vós eu quero

Nada posso consegui!

${ }^{16}$ Luciana Hartmann (2000) faz referência à surpresa como uma prática de sociabilidade presente na região sudeste do estado gaúcho.

Horizontes Antropológicos, Porto Alegre, ano 19, n. 39, p. 293-318, jan./jun. 2013 
Em relação ao verso explicou: "Tá se queixando, né!”

Lembra dos bailes na casa de "Picucha Marque” quando "à noite, a gente ia longe só à base de verso... um cantava um, otro cantava otro!” Mencionou que a realização do baile dependia de alguns critérios, pois "tinha que tê licença da prefeitura”. Para tanto, pagava-se um imposto mediante "um talãozinho”, ensinou seu Juca.

Nas narrativas das pessoas muitas vezes acontecimentos como puxirões, surpresas, bailes e festas se misturam. Na realidade, dentro do sistema agrícola missioneiro, tais eventos lúdicos só poderiam efetivar-se em períodos de boa colheita ou de abundância nas criações de animais domésticos.

Seu Pedro Tufão contou que certa vez fizeram surpresa durante "uma semana toda. Em todas as casa: uma vaca e um barril de vinho!... Eu dançava a noite intera e de dia trabaiava o dia intero! De primero se dançava, se divertia. Não havia nada!”

Mencionou ainda o episódio em que participou de um baile onde cantou muito, pois gostava de música. As pessoas, naquela noite, apreciaram a sua performance. Ele, entretanto, bebeu demais - também gostava de "tomar" e acabou sendo levado à casa do delegado completamente embriagado. No outro dia, sem saber como teria chegado naquele local, perguntou ao homem como fora parar ali. Ele respondeu que tinha gostado muito de sua "cantoria", por isso resolvera dar-lhe pouso naquela noite. Dona Josefina, por sua vez, conta que "tocava gaita em baile” em Giruá, onde morava. Já dona Cleni lembrou que "era dançadera em quantia!” Ambas referem-se a um tempo anterior à sua conversão ao pentecostalismo, pois tais atividades lúdicas são consideradas interditas.

Seu Milton, quando conversávamos em sua casa no centro de São Miguel, rememorou dois episódios. Primeiro, o casamento dos pais de Mara que me acompanhara até a sua casa: "Tem coisa que a gente grava na ideia. Parece que eu tô vendo o movimento da festa!” Segundo, as festas na casa de Pedro Mandioca: “Aquelas festas eram lindas... faziam linguiça em quantidade!”

Os bailes e as surpresas, ao combinarem comensalismo, danças e cantorias, representavam um “divertimento”, pois conforme seu Emílio, no caso do puxirão, “depois do trabaio iam se diverti”. Dona Cleni diz que era "uma brincadeira bonita”, concluindo, "a gente tem saudade desse tempo bonito que não volta mais!” 
Mas havia a possibilidade de "furar a surpresa”, explicaram. Quando alguém suspeitava que receberia a visita de pessoas, deveria ficar "cuidando", pois caso não quisesse ser premiado, antes da chegada dos foliões deveria disparar alguns tiros para cima, sinalizando assim que estava furando a surpresa. Segundo o casal "não é que nem hoje” quando, seguidamente, ocorrem brigas nas festas.

Seu Milton, ex-subprefeito de São Miguel, e sua esposa, dona Zeza, disseram que a surpresa também ocorria no aniversário de uma pessoa. Novamente o evento está relacionado a datas cíclicas. Da mesma forma, um grupo de pessoas irrompia na casa do aniversariante. Alguns deles em meio a toques de gaitas, cantorias e danças, “carneavam” um animal que pertencia ao aniversariante e assim sucedia-se a festa. Ressaltam que tudo envolvia um clima de "brincadeira”, pois "ninguém se ofendia” com a surpresa. Além disso, "do jeito que começava, terminava!”

Perguntei a seu Pedro Tufão se ele tem saudade desse tempo e ele respondeu: "Muita, muita, mas esse tempo não vem mais. O modernismo, os grande tomaro conta!"

“Ôla tempo bom!”, exclamou seu Milton.

\section{Considerações finais}

O paulatino desaparecimento das atividades mistas de trabalho e de experiência lúdica aponta para o fato de que as práticas capitalistas, ligadas à monocultura extensiva e à utilização das máquinas agrícolas nas atividades de trabalho na zona rural gaúcha, engendraram um duplo impacto sobre as paisagens missioneiras. Primeiro, porque tais práticas estabeleceram rupturas nos laços de solidariedade presentes nas diversas comunidades que eram tradicionalmente cultivados e que revelavam a dimensão sensível do "homem missioneiro" no que tange aos ritmos temporais, envolvendo o cuidado com os ciclos das estações, as lunações e o calendário do catolicismo popular nas localidades. Segundo, porque tais práticas aceleraram os processos de degradação física das paisagens devido ao empobrecimento da biodiversidade - com o desaparecimento de espécies animais e vegetais que compunham as paisagens praticadas pelos missioneiros -, fenômeno provocado pela introdução sem critérios de tecnologias duras no campo voltadas à monocultura extensiva, 
substituindo técnicas mais suaves de manejo dos ambientes mantidas de forma tradicional e inserindo a lógica da lavoura mecanizada, dependente de insumos agrícolas na região missioneira. A perda da diversidade ecossistêmica, portanto só pode ser pensada na sua relação direta com a perda da diversidade cultural que, todavia, emerge como "potência subterrânea" através da sutileza do "trabalho da memória” entre os narradores missioneiros.

\section{Referências}

ANDERSON, A. B.; POSEY, D. A. Reflorestamento indígena. Ciência Hoje, Rio de Janeiro: SBPC, v. 6, n. 31, p. 44-50, 1987.

AVÉ-LALLEMANT, R. Viagem pela Província do Rio Grande do Sul (1858). Belo Horizonte: Itatiaia; São Paulo: EdUSP, 1980.

BACHELARD, G. A poética do espaço. São Paulo: Martins Fontes, 1988.

BACHELARD, G. A Terra e os devaneios da vontade: ensaio sobre a imaginação das forças. São Paulo: Martins Fontes, 1991.

BATESON, G. Mente e natureza: a unidade necessária. Rio de Janeiro: Francisco Alves, 1986.

BATESON, G. Os homens são como planta: a metáfora e o universo do processo mental. In: THOMPSON, W. I. Gaia: uma teoria do conhecimento. São Paulo: Gaia, 1990. p. 35-44.

BESCHOREN, M. Impressões de viagem na Província do Rio Grande do Sul. Porto Alegre: Martins Livreiro, 1989.

BOSI, E. Memória e sociedade: lembranças de velhos. São Paulo: Companhia das Letras, 1994.

BROCHADO, J. P. O Guarani: conquistador vencido. In: O ÍNDIO NO RIO GRANDE DO SUL - PERSPECTIVAS: aspectos arqueológicos, históricos, etnográficos e étnicos. Porto Alegre: Governo do Estado do Rio Grande do Sul, 1975. p. 71-81. 
CANDIDO, A. Os parceiros do rio Bonito. Rio de Janeiro: Livraria José Olympio, 1964.

CERTEAU, M. de. A invenção do cotidiano: artes de fazer. vol. I. Rio de Janeiro: Vozes, 1994.

DIEGUES JR., M. Regiões culturais do Brasil. Rio de Janeiro: Centro Brasileiro de Pesquisas Educacionais/Ministério da Educação, 1960.

DURAND, G. Science de l'homme et tradition. Paris: Berg International, 1979.

ELIADE, M. O mito do eterno retorno. São Paulo: Mercuryo, 1992.

FREYRE, G. Problemas brasileiros de antropologia. Rio de Janeiro: Livraria José Olympio: MEC, 1973.

HARTMANN, L. Oralidades, corpos e memórias: performances de contadores e contadoras de causo da Campanha do Rio Grande do Sul. Dissertação (Mestrado em Antropologia Social)-Centro de Filosofia e Ciências Humanas, Universidade Federal de Santa Catarina, Florianópolis, 2000.

HAUBERT, M. Índios e jesuítas no tempo das missões. São Paulo: Companhia das Letras, 1998.

HOLANDA, S. B. de. Cobra de vidro. São Paulo: Perspectiva, 1978.

KERN, A. A. Missões: uma utopia política. Porto Alegre: Mercado Aberto, 1982.

KERN, A. A. O processo histórico platino no século XVII: da aldeia guarani ao povoado missioneiro. Estudos Ibero-Americanos, Porto Alegre: PUC, v. 1, n. 11, p. 23-41, 1985.

KERN, A. A. Arqueologia histórica missioneira. In: SIMPÓSIO NACIONAL DE ESTUDOS MISSIONEIROS, 7., 1998, Santa Rosa. Anais... Santa Rosa: Faculdade de Filosofia e Letras Dom Bosco, 1998. p. 184-194. 
LEROI-GOURHAN, A. O gesto e a palavra: 2 - memória e ritmos. Lisboa: Edições 70, 2002.

MAFFESOLI, M. O tempo das tribos: o declínio do individualismo nas sociedades de massa. Rio de Janeiro: Forense-Universitária, 1987.

OLIVEIRA, R. R. et al. Roça caiçara um sistema “primitivo” auto-sustentável. Ciência Hoje, Rio de Janeiro: SBPC, v. 18, n. 104, p. 44-51, 1994.

PRUNES, L. M. A humanização da paisagem natural. In: RIO GRANDE DO SUL: terra e povo. Porto Alegre: Globo, 1969. p. 15-27.

RAMBO, B. A fisionomia do Rio Grande do Sul. São Leopoldo: Ed. Unisinos, 1994.

ROCHA, A. L. C. da. Nas trilhas de uma bioetnodiversidade: a questão do olhar do Outro e seus desdobramentos na construção dialógica das ciências ambientais. Porto Alegre: Instituto Anthropos, 2000. Mimeografado.

RUBERT, R. A. Construindo tempos, recompondo tradições: um estudo etnográfico de memórias junto a velhos moradores de um contexto rural Região do Médio Alto Uruguai (RS). Dissertação (Mestrado em Antropologia Social)-Instituto de Filosofia e Ciências Humanas, Universidade Federal do Rio Grande do Sul, Porto Alegre, 1999.

SAHLINS, M. Ilhas de História. Rio de Janeiro: Jorge Zahar, 1990.

SCHMITZ, P. I. O guarani no Rio Grande do Sul: a colonização do mato e as frentes de expansão. In: SIMPÓSIO NACIONAL DE ESTUDOS MISSIONEIROS, 3., 1979, Santa Rosa. As Reduções na época dos Sete Povos. Santa Rosa: Faculdade de Filosofia, Ciências e Letras Dom Bosco, 1979. p. 55-74.

SILVA, B. O. Missões: um vocabulário à parte: assim se falava no campo e na cidade em São Borja nas décadas de 1940-1950. Porto Alegre, 2000. 
SILVEIRA, F. L. A. da. As paisagens fantásticas e o barroquismo das imagens: estudo da memória coletiva dos contadores de causos da região missioneira do Rio Grande do Sul. Tese (Doutorado em Antropologia Social)-Instituto de Filosofia e Ciências Humanas, Universidade Federal do Rio Grande do Sul, Porto Alegre, 2004.

SIMMEL, G. Sociabilidade. In: MORAES FLHO, E. (Org.). Simmel. São Paulo: Ática, 1983. p. 165-181.

XAVIER, P. A estância. In: RIO GRANDE DO SUL: terra e povo. Porto Alegre: Globo, 1969. p. 75-87. 